\title{
STK32B Gene
}

National Cancer Institute

\section{Source}

National Cancer Institute. ST K32B Gene. NCI Thesaurus. Code C158546.

This gene is involved in protein phosphorylation and limb development. 